BARTHES, A. \& LANGE, J.-M. (2017). Researchers' positions and construction of curricula of education for sustainable development in France. Journal of curriculum studies; Vol. 50, (1), 96-112.

(C) 017 Informa UK Limited, trading as Taylor \& Francis Group

\title{
Researchers' positions and construction of curricula of education for sustainable development in France
}

\author{
Angela Barthes ${ }^{1}$ and Jean-Marc Lange ${ }^{2}$ \\ ${ }^{1}$ EA ADEF, Aix-Marseille University, Digne, France; \\ ${ }^{2}$ EA LIRDEF, Montpellier University, Montpellier, France
}

\begin{abstract}
The article sets the international context for the development of a curriculum of education for sustainable development and shows the directions being taken in the Francophone community. Building on a significant number of studies carried out in France, we constitute a typology of the positions of French-speaking researchers involved in those studies and contributing to the establishment of the national curriculum. This typology is constructed using a methodology based on the frequency of lexical occurrences in a bibliographic database, combined with a methodology of research on the social representations of the researchers of this community. We first present a broad comparison with the Anglo-Saxon sphere, we postulate that these positions influence the curriculum construction and raise the issue of the social responsibility of education science researchers in the face of international political demands.
\end{abstract}

\section{KEYWORDS}

Education for sustainable development; curriculum; researchers 'positions; France

\section{Introduction}

In accordance with UN/UNESCO prescription, education for sustainable development (ESD) emerged in France, in the early 2000, in the wake of the international development of environmental education (Jickling \& Wals, 2008; Lucas, 1991; Reid \& Dillon, 2015; Smyth, 1995). The specificity of ESD, its explicitly political nature, institutional instability and position as an emerging curriculum, have brought to light issues that concern all curricula (Fien, 1991; Goodson, 1983 Gough, 1989; Reid, 2015).

Research in both the Francophone and English-speaking worlds, approach the issue of the curriculum by stressing the necessary articulation between the political, strategic and programmatic perspectives. Thus, the formal curriculum appears as a political issue, which varies according, among other things, to the degree of centralization of education systems.

That is why, in line with the research conducted by English speaking scholars (Reid, 2015), we propose to examine the question of ESD in France and look at how it is addressed by French researchers. For this purpose, we identify various positions found in the French research community and discuss their national implications in terms of curriculum development.

\section{Issues pertaining to the curriculum of ESD in France}

Today, just as in the past, supra-national political bodies can influence the local or national curriculum. This is true, for example, in the case of the implementation of the Decade of ESD (20042014) by UNESCO-as an executive agency of the UN. The implementation of this project has been 
accompanied by academic research undertakings. Among them, the research group 'Education for sustainable development- supports and barriers' (ED2AO), supported by the ANR1 and its international networks, have initiated pioneering studies on formal and informal curricula related to the emergence and generalization of ESD, and in various educational forms and context. Thus, sustainable development potentially falls within the scope of controversial socio-scientific issues, also called socially acute issues, which are considered an educational challenge for society (Levinson, 2006), as shown, for example, by the studies on the emblematic question of climate change (Fahey, 2012; Levinson, 2012).

Sustainable development is, indeed, a political idea. It is therefore necessarily challenged (Jacobs, 1998; Jickling \& Wals, 2008). Envisaged initially as a means of embarking on a virtuous path in terms of environmental protection, sustainable development can, for some authors, be considered as a failure because of the inability to reconcile growth and reduce the environmental impact, especially on resources (Foster, 2011; Zaccai, 2011). However, the value of this idea lies in its having firmly placed in international political agendas, the question of development sustainability and that of development itself, 2 as well as that of a necessary development of critical education (Greenall Gough \& Robottom, 1993; Greenwood, 2008).

There remains, therefore, to develop a new grammar of this primarily political and galvanizing idea (Theys, 2014). While, education is considered to be the condition and the means of promoting sustainable development, it is subject to the ideological risk of being exploited to serve a economistic (Sauvé, 2006) or even a techno-economistic world vision (Morin, 2014; Theys, 2014), which would then constitute the hidden curriculum of this education (Barthes \& Alpe, 2013; Greenall Gough, 1991). The teaching of sustainable development is conditioned by specific epistemological and didactic positions (Fien, 1991; Goodson, 1983; Gough, 1989; Simonneaux, 2011), whose legitimacy is also debated and even challenged. These positions have a great impact in terms of potential variability in curriculum elaborations and didactic transpositions, which are associated to sometimes divergent and conflictual societal priorities. Thus, Ross (2000) has characterized three ideal types of curriculum development models, and has emphasized that these possible strategic choices and orientations are ideologically marked.

In this context, examining the different positions of researchers in response to the emergence of ESD seems essential, and provides a representative overview of the positions adopted by the 'noosphere'. We propose to do so in the French-speaking community. Given the complexity of the task and the intellectual and applicative implications of this exercise, this article provides a preliminary analysis of the positions to consider, not as a final research result, but as the basis for future collective research and for comparison with the positions of Anglo-Saxon scholars.

\section{Corpus and methodology}

To this end, we have set up a solid working methodology based on two corpuses, studied according to two different processes, providing us with key indicators. Corpus 38 Researchers in the field of ESD 98 Works published about ESD (2008-2015)

\begin{tabular}{lll}
\multicolumn{2}{c}{1} & \multicolumn{1}{c}{2} \\
\hline Corpus & 38 Researchers In the field of ED & 98 Works published about ESD (2008-2015) \\
Methods & Soclal representations & Content studles \\
Indicators & Frequency of lexical occurrences Co-occurrences & Frequency of lexical occurrences \\
\hline
\end{tabular}

The first corpus of 38 researchers' positions was developed on the basis of a questionnaire completed by the researchers participating in the ED2AO programme (or from the Frenchspeaking part of the 'noosphere'), one year before the end of that project (2012). This research project can be considered central in the French context as it brought together many of the researchers interested in the topic of ESD, at a time corresponding to phases 2 and 3 of the process of expansion of this type of education in the French education system.

The questionnaire aimed to reveal the researchers' social representations concerning sustainable development and ESD. Social representation is understood here as 'natural' knowledge, a form of 
knowledge that enables individuals to integrate a reality and adapt their behaviour according to their representation. Abric (1994) argues that it is an appropriation of the object through cognitive reconstruction, which is shaped by the social and ideological context. It was therefore considered that the study of social representations took on a particular dimension in the context of this socially acute question of sustainable development (Legardez, 2004), insofar as it provides a framework for interpreting 'natural knowledge', known information, how it is structured, and the behaviour of individuals towards the represented objects. The representational contents in the noosphere were analysed via a 'spontaneous response' questionnaire: 'What words or phrases come to mind when you think of ESD?' Thirty-eight respondents then proposed a list of about 10 words, which is a total of 378 words quoted and available for study. These constitute the second corpus. The meaning of the used world has been completed, as usual in social representations, by interviews of explicitation (Vermersch, 2011).

Thus, the second stage of our work involved understanding the structure of the responses. For this purpose, we constructed graphs of co-occurrences-that is to say, a calculation of the number of links between the words quoted. For example, if individual ' $A$ ' respond with the words ' $x$ ' and ' $y$ ', then there is a co-occurrence of ' $x$ ' and ' $y$ '. The sum of all these co-occurrences is calculated for the 38 individuals. The number of co-occurrences is then represented in a graph. The higher this number, the thicker the lines connecting the words.

During this process, the terms were clustered according to their co-occurrences; But, as a result, clusters of unconnected words (or only connected through the two common terms 'education' and 'sustainable development') emerge. This process enabled us to group the responses of the researchers into the same number of self-organized categories. This yielded six families of interconnected words corresponding to different positions. These six families constituted the corpus used for analysing the researchers' positions. Indeed, building on this basic data (the six families of words), we looked for the bibliographic corpus to which these six families of words were connected. Thus, the 154 words selected from the bibliographic inventory, were linked, and added, to the words included in those six families. And it is on the basis of these six families, each associated with words extracted from publications linked to it, that we were able to conduct a 'literary' analysis of the researchers' positions (therefore, divided into six categories), determining the meaning of the words used in the original texts then considered as a significant basis3 (For method details concerning social representations studies for sciences education, see Barthes \& Alpe, 2016).

The second corpus, strictly bibliographical, was constructed from the inventory of the works published during the ED2AO research project (2008-2012) and its extensions (2013-2015).

The inventory lists the 98 works published by the members of ED2AO and its partners-inthe wide sense of the term - whether they are isolated researchers or international institutional partners, with whom many exchanges of views have taken place. Those publications collective works, such as : that on 'Le développement durable et autres questions d'actualités, les questions socialement vives dans l'enseignement et la formation' (Sustainable development and other current issues, socially acute questions in education and training) (Legardez \& Simonneaux, 2011) or 'Éducation, environnement et développement durable : Vers une écocitoyenneté critique' (Education, environment and sustainable development : towards a Critical Eco-Citizenship) (Bader \& Sauvé, 2011); journals' issues such as Spirale $n^{\circ} 50$ on 'educations for ...' (Pagoni \& Tutiaux-Guillon, 2012), Education relative à l'environnement: Regards-Recherches-Réflexions, $n^{\circ} 10$ (Environment-related education : viewsresearch- reflections) $n^{\circ} 10$ (Bidou, 2012), $n^{\circ} 11$ (Bader, Barthes, Legardez, \& Sauvé, 2013) and $n^{\circ} 12$ Sauvé \& Van Steenberghe, 2013), les Dossiers des sciences de l'éducation $n^{\circ} 29$ (Dossiers on educational science $n^{\circ} 29$ ) (Simonneaux \& Calmettes, 2013), the Journal of social science

education $n^{\circ} 11$ (Simonneaux, Tutiaux-Guillon, \& Legardez, 2012), Environmental education research $n^{\circ} 18$ and 19 (Reid, 2012, 2013), la Revue francophone du développement durable $n^{\circ} 1$ (Francophone journal of sustainable development $n^{\circ} 1$ ) (Diemer \& Mulnet, 2013), penser l'éducation hors-série 2013 (Lange, 2013) In addition, the corpus includes proceedings of seminars : 'Education au développement durable et à la biodiversité' (ESD and biodiversity), Digne les Bains, 20-22 October, 2010 (Alpe \& Girault, 2011); 'Rapport aux savoirs, éducation relative à l'environnement et 
au développement durable' (relations to knowledge, education relative to the environment and sustainable development), 80th ACFAS congress, 8-9 May, 2012 Montréal (Bader, Barthes, Legardez, \& Sauvé, 2013); 'Les représentations Nord-Sud du développement durable' (North/South representations of sustainable development), Clermont-Ferrant, 8-10 December, 2012 (Diemer \& Mulnet, 2012); 'L'éducation au développement durable : appuis et obstacles à sa généralisation hors et dans I'Ecole' (ESD: Supports and barriers to its expansion at and outside school), Rouen, 26-28 November, 2012; and all isolated publications by researchers between 2008 and 2014.

The inventory then enabled us to conduct an analysis of the lexical occurrences in the corpus, using the Tropes software, 4 and to record those occurrences in an Excel table.5 This yielded a list of 9551 different terms. The frequencies of occurrences were then discretized (aggregated into classes) using the amplitude method. 6 We only considered the first class, which was deemed significant based on this criterion-generally, the words quoted more than 50 times: Thus, 154 words were eventually used for the analysis. These words, which were extracted from publications, constitute the second indicator used for the study. These indicators are used to verify the connection between studies of the social representations and to specify their meaning.

\section{Results}

The responses showed, first of all, that the researchers did not share the same social representation of ESD. Indeed, the members of a community are considered to share a social representation only if several words are used by at least $30 \%$ of the respondents, considering usual social representations epistemology and method (Barthes \& Alpe, 2016). In this case, the dispersion of the terms is such that we only found four shared words, which had little significance in this context: education, training, teacher and sustainable development.

This is in no way surprising given the many discussions that punctuated all meetings held throughout the research programme in repeated attempts to reach a consensual definition of the object of study. Although it was studied in its curricular aspects and in many different contexts, particularly in terms of its implications, the object 'SD' remains a polysemous concept. The Anglo-American understanding of the term is controversial (Jacobs, 1998) for the French research community and the latter has therefore not reached a consensus on the topic.

The results are presented in six graphs of co-occurrences:

The analyses show that various positions exist among researchers and that they can be found in the six categories (Graphs 1-6). To characterize these positions, we then used the main components of the graphs of co-occurrences (the words and their main links) associated with the 154 terms extracted from the publications used as additional indicative guides, and examined the publications themselves when specifications were required. From that point onward, we produced a word of the different, self-organized, positions and named them, on the basis of the central terms in the cooccurrence graph that describes them.

Once this stage was completed, we were able to define more the following six classes, helped by bibliographic indicators and interviews of explicitation. We name and present them below.

\section{Characterization of researchers' positions concerning ESD}

The first position, that of the 'accepting' consists in adopting, de facto, the concept of SD. The researchers in this class accept the concept of SD as a basis for their work. The studies they undertake are based on their almost 'natural' integration of the concept, without involving real critical distance, either in relation to this new ideology, or in relation to the new scientific practices that it implies. We observe a surreptitious introduction of the term 'sustainable' scientific language; a scientific language undergoing a lexical rather than semantic transformation-in line with political directives-into a kind of newspeak denounced by others (Bonneuil \& Fressoz, 2013). This position concerns a large number of studies and is characterized by the researchers' acceptance of a change in vocabulary imposed by the political ideology, but without the latter generating any shift in the scientific approach, any particular reflection on the subject. This position is most often observed in isolatedcase studies or in research/actor interactions characterized by a lack of critical distance. 
These researchers describe field experiences and seem to adopt their orientations, as though the sometimes militant positions of education practitioners were self-evident and needed to scientifically legitimated. Consequently, there seems, as yet, to be no research movement built around this position and characterized by any specific lexical field or method.

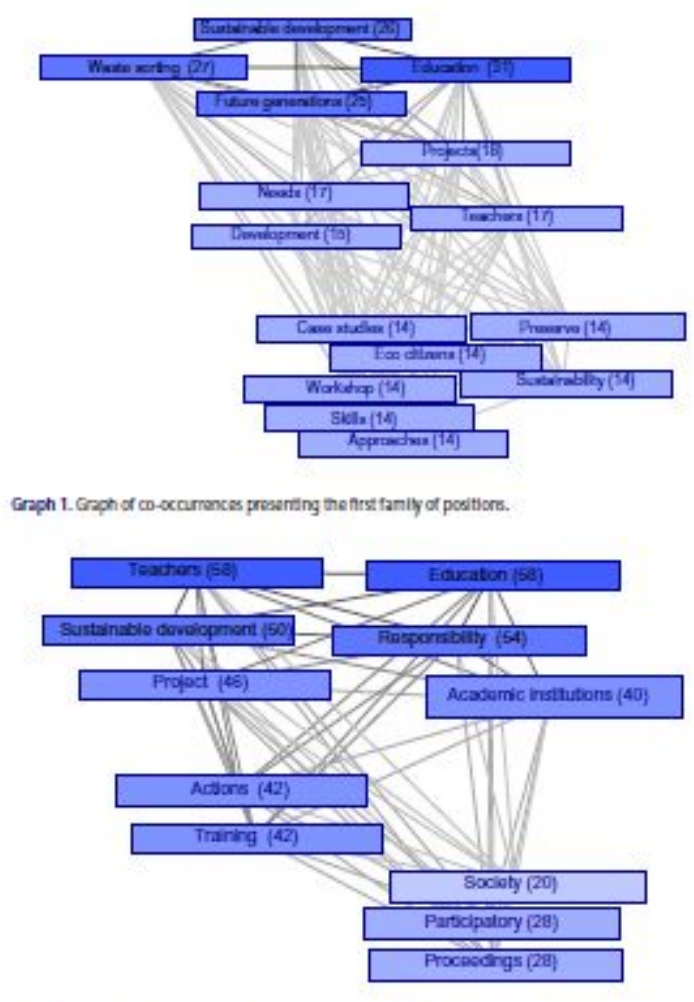

Graph 2 Groph of co-ocrumences proserning the second tamly of postions.

The second position, that of 'the individuals describing/prescribing new procedures' consists of using the concept of sustainable development as a basis to produce a new mode of knowledge creation. This involves reassessing the knowledge produced through research by taking into account issues related to sustainable development. The studies in this group do provide analyses of sustainability but fail to analyse the foundations on which sustainable development can be realized, and are based on an inference principle that can sometimes lead to a lack of robustness. This position is frequently adopted by researchers trying to analyse the introduction of new procedures, such as green chemistry (Ducamp, 2011), Agenda 21 (Lebatteux, 2011), or its application by teachers (Sarda, 2011). A thorough description of the new procedures is then developed and serves to model their implementation.

The third position, that of the 'systemic' consists in approaching ESD by taking into consideration the relevance of temporal and spatial categories, as well as its systemic aspects, in order to envisage the introduction of ESD in its complexity. The researchers who adopt this theoretical position recommend considering development as 'necessarily engaged in multiple interactions with other places, which must be intelligible from different spatial scales ranging from the local to the global, and which involve relations of domination and competition, implying conflicts, collective choices, trade-offs' (Mathieu, 2006, p. 58). This position draws attention to existing tensions and contradictions in the concept and to the urgent need to precisely define the scope of relevance of such a problem. This position is strongly represented among researchers interested in territory related issues (Barthes \& Champollion, 2012)-such as those among geographers and economists who study educational issues (Barthes et al. 2013; Diemer, 2011; Tutiaux-Guillon, 2011; Vergnolle-Mainar, 2011) - and is supported by the Swiss research team (Audigier, 2011a). 


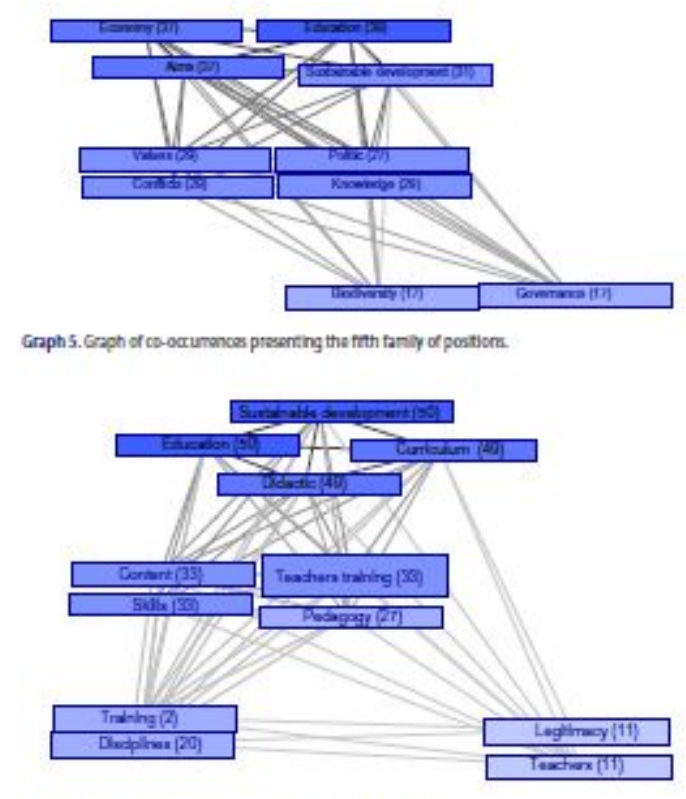

The fourth position, that of the 'controversies' consists of stating, from the offset, the objective of building a common object of study, i.e. ESD, whose social dimensions (representations, practices, controversies, risks) cannot be dissociated. But for this hybrid object to meet the challenge of what appears to be a political utopia, it is necessary to approach it as such (as an acute question), to untangle the complex causal system and to identify and evaluate opportunities to shift towards solutions that reconcile often conflicting, and even incompatible objectives, and, finally, to detect actual or potential conflicts of interest. Ensuring and implementing ESD [...] implies organizing the reflection on education around a specific issue, or a socially acute question, laden with controversy (Urgelli, Simonneaux, \& Le Marec, 2011) and risk, and conducive to educational innovation. This is evidenced by the introduction of simulation games (Vidal \& Simonneaux, 2011), serious games (Genevois \& Leininger- Frezal, 2011), multi-agent systems, or by the limitations of education (Moreau, Brugiere, \& Triquet , 2012). A school of thought representing this position is that of Aix and Toulouse (Legardez \& Simonneaux, 2006, 2011; Simonneaux \& Simonneaux, 2012). It is partly adopted by Quebec researchers and is sometimes combined with the critical position (Groleau \& Pouliot, 2013; Bader, Arseneau, Therriault, \& Lapointe, 2013). This position is also, in some cases, combined with philosophical considerations (Martinez, 2006). 


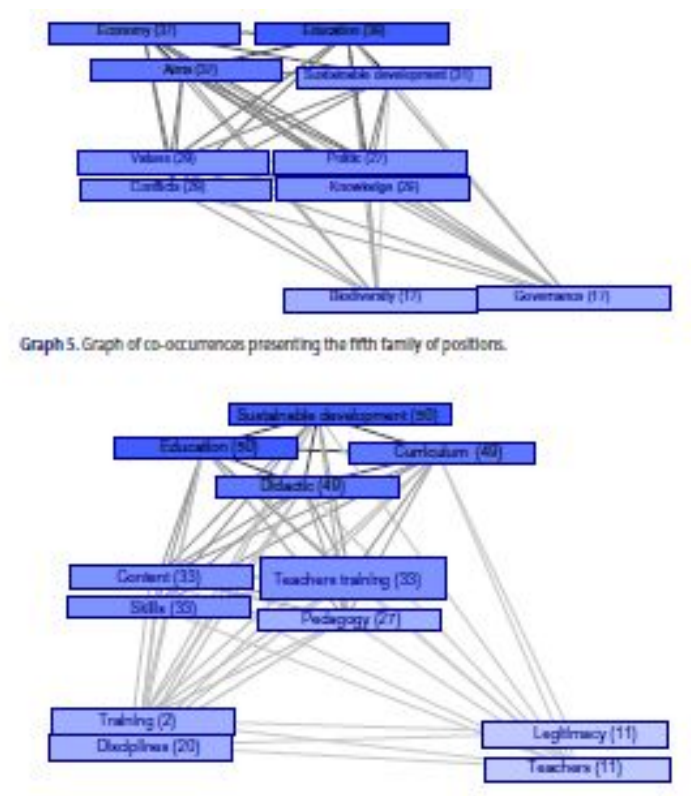

Graph 6. Graph of co-occumences presenting the sxth family of positions

The fifth position, that of the 'critical', emerges in a context where ESD imposes itself as a frame of reference. The latter is the subject of national/international educational projects that offer an opportunity to reflect on the teaching contents of ESD and on their dominant and invasive nature (Jicking, 2008, 2009; Robbotom \& Hart, 1993; Sauvé, 2006; Sterling \& Scott, 2008). It also prompts reflection on 'the meaning of education, which is now put at the service of a development, intended to be sustainable' (Girault \& Sauvé, 2008, p. 33). This position leads to a distancing from sustainable development and from ESD through the underlying of the practices resulting therefrom, and opens itself up to alternative positions. Fortin-Debart and Girault (2006, p. 41) state that 'This critical approach has little penetrated field of educational practices' and yet, open up possibilities of reflection and controversy in the construction of multi-paradigmatic knowledge. This position is very well represented in the Quebec school (Sauvé, Berryman, \& Brunelle, 2003) and in the Anglo-Saxon community Jickling, 2009) and extends into France (Barthes \& Alpe, 2012; Barthes, Bader, \& Alpe, 2012; Barthes \& Jeziorski, 2012; Barthes, Zwang, \& Alpe, 2012; Girault, Zwang, \& Jesiorski, 2012).

The sixth, highly 'didactic' position, consists of paying particular attention to curriculum construction, its difficulties and potentialities, by exploring the various possible approaches (Lange, 2012; Lange \& Martinand, 2010, 2011; Lebeaume, 2012). Attempts are also being made to integrate alternative teaching modalities, often with the idea of a different curriculum construction (Bidou, 2011; Chevallard \& Ladage, 2011; Giral \& Legardez, 2011; Lange, 2014b), which often counterbalances the questions in science didactics concerning disciplines or the legitimacy of the teachings. Questions regarding teacher training are also raised (Lebeaume $\&$ Lange, 2008) as well as issues concerning changes or difficulties in the various disciplines (Audigier, 2011a; Lange, 2014; Vergnolle-Mainar, 2011). This didactic stance sometimes has its roots in the previously mentioned approaches such as, for example, the critical position (Brière, Sauvé, \& Jicking, 2011) or that of controversies (Simonneaux \& Simonneaux, 2012). It sometimes has an epistemological dimension, in which case it is inspired from the educations for' movement (Albe, 2012; Lange, 2014b).

\section{Discussion}

This essay on the positions of researchers in response to the emergence of ESD provides a snapshot of the community of the researchers involved in the Francophone research programs associated with the ESD decade network (2004-2014). This first overview shows at least the polysemic nature of ESD and of the different senses given to the term; it also reveals the emergence of various, more or less compatible positions. Thus, one of the authors of article recognizes itself more in the critical posture 
and the other in the didactic posture. This presentation of the different positions serves as a framework for interpreting what is undertaken, at a given time, by the French-speaking scientific community in command of curricular development, and the basic doctrinal choices, which may shape didactic work. A researcher is obviously characterized by more complexity: The position of an individual is not set in stone and one position may be combined with others. An individual evolves as time and debates go by and according to the general collective orientation. Thus, without losing sight of the complexity of individual thoughts and of the power relations at play in the debates held in the context of research programmes, this interpretive grid provides a basis for a detailed and evolving collective reflection and is not a fixed result of research. However, the heterogeneity of the positions, the lack of social, or in other words, of shared representations, highlighted in this study are probably an important factor in the orientation of the prescribed or produced curriculum, but they are without a doubt an important parameter in the direction of a possible curriculum for ESD. Furthermore, given the particular subject of this essay, ESD, it is also probably revealing of the other 'educations for'.

The positions, as they are described above, also implicitly reveal that the three orientations proposed by Godard (2001) are actually at work in the community of researchers in educational science, and involve three modalities of researchers' social responsibility. Some researchers only respond to the social demand as they would to any other demand (the 'Accepting'). Others are more in favour of reproblematizing the existing contents but without questioning the basis on which the recommendation is made ('descriptors/prescribers') and of envisaging research as a means of enriching institutional recommendations. Others tend to favour a critical deconstruction of the object ('critical positions'), using their conceptual elaborations and methodology as a basis for this endeavour, based on an examination of institutional recommendations. Finally, there are researchers who explicitly question their practices and call for the development of new research procedures (the 'systemic', the 'didactic'), taking 'seriously' the implications of alternative directives, and approaching the question from an external and/or internal viewpoint. The graph below summarizes these relationships:

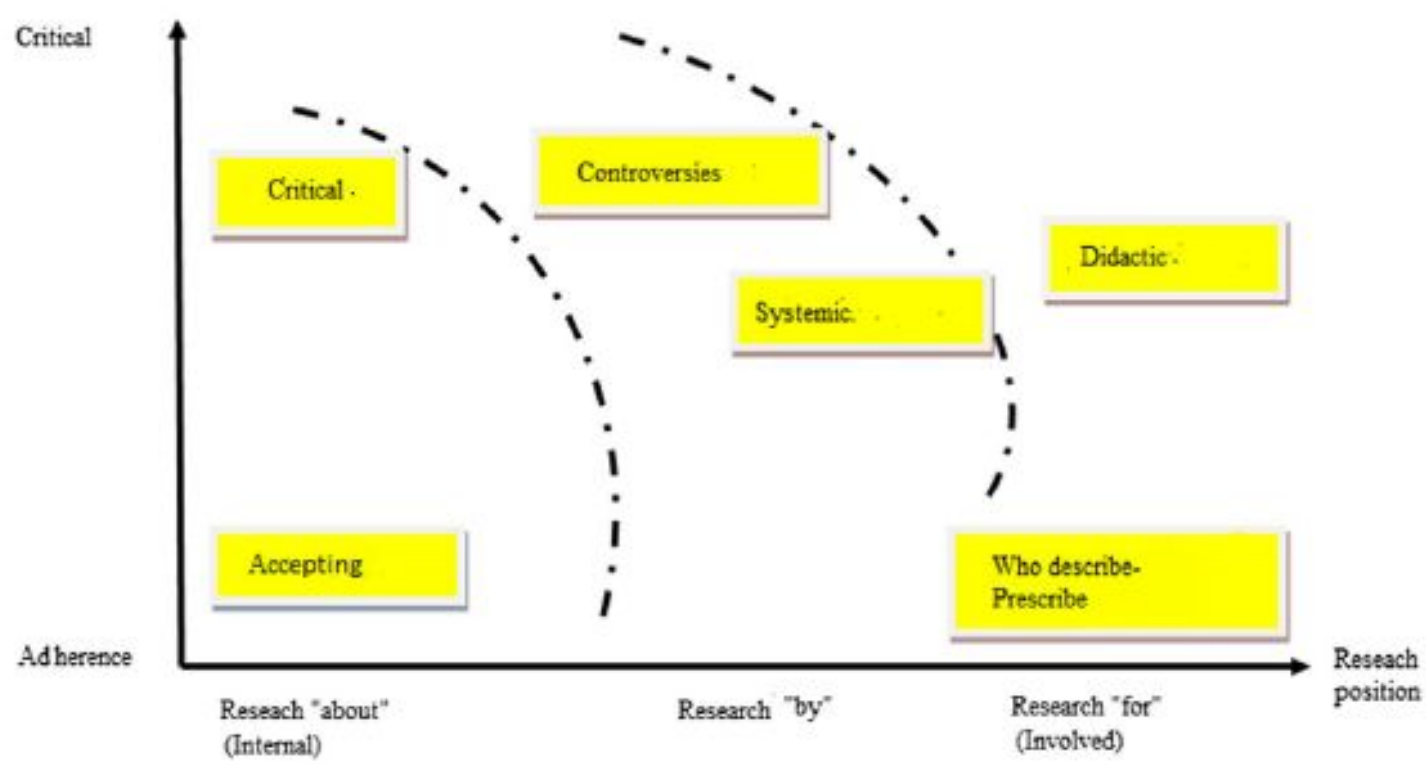

Graph 7. Positions and conceptions of research.

These different positions, which correspond to the different ways in which researchers respond to their social responsibility (Graph 7), lead to negotiations, power relations or collaborations that result in curricular recommendations, which are then examined by State institutions. These positions structure the type of research that is conducted, and give rise to different curriculum possibilities (Morris, 2002). They also add to the heterogeneity and fluctuations in institutional propositions (the 
prescribed), which generates confusion among practitioners and therefore makes implementations more difficult (self-prescribed). Faced with this unstable situation, most of them probably prefer to fall back on their customary practices.

A study on the English-speaking community, based on a similar methodology, should obviously be undertaken to identify the similarities and differences between French and English speaking researchers, and their results in terms of national curricula. The positions of Francophone researchers probably have characteristics in common with those of English-speaking researchers, but a study of the Anglo-Saxon research community is necessary in order to truly identify the similarities and differences in the views and rationales that characterize each community. However, it appears, at least in light of the publications we examined, that the critical stance is quite common in the Anglo-Saxon community (Greenall Gough \& Robottom, 1993; Jickling \& Wals, 2008). Similarly, we find that the views of those describing/prescribing new procedures are also strongly represented among English speakers (Gayford, 1986; Greenwood, 2008; Lee, 2000; Ross, 2007). The 'controversy' approach also has followers (Levinson, 2006, 2012), and the epistemological questions seem to be raised more frontally in the Anglo-Saxon community (Goodson, 1983; Gough, 1989; Moroye, 2009). It appears furthermore that the view advocating citizen participation (Dillon, Stevenson \& Wals, 2016) is much more common in the English-speaking than in the French-speaking community.

\section{Conclusion}

The curriculum question, as it is raised by researchers, synthesizes the tension between various objectives: objectives of knowledge creation, objectives in terms of comprehension and praxeological objectives. Thus, the existing research studies have not only influenced the orientations of the 'noosphere', but also probably the institutional curriculum propositions, and even the actual implementations by practitioners. Not only do they reflect those tensions, but the views they present are rooted in researchers' implicit or explicit conceptions of their social responsibility and in their relationship to the object of study, including in ideological terms.

The study reported here, has identified six positions observed among French-speaking researchers; positions which structure the construction of curricula. This first overview contributes to revealing the tensions at work in the Francophone community. Those tensions probably have a crucial impact on the ways in which international recommendations (in the form of missions) are applied, in the long term, on the national education system and on the strategic orientations or actual educational practices. A similar study, using the same methodology, should be conducted on English-speaking researchers in order to identify the similarities and differences between both communities.

\section{References}

Abric, J.-C. (1994). Pratiques sociales et représentations [Practice and social représentations]. Paris: PUF.

Albe, V. (2012). Des sciences à fortes vivacité sociale à l'école: entre disciplines et éducations in Pagoni et Tutiaux Guillon Les éducations à, quelles recherches, quels questionnements? Spirale, 50, 67-80.

Alpe, Y., \& Girault, Y. (2011) (dir.). Actes du colloque international « Education au développement durable et à la biodiversité : concepts, questions vives, outils et pratiques " Université de Provence, Muséum National d'Histoire Naturelle-IRD, ENS Cachan, 20-22 octobre 2010 Digne les Bains. Retrieved from https://www.refere.uqam.ca/FR/publications_mono.php

Audigier, F. (2011a). Penser les temporalités pour penser les questions sociales vives, éduquer au développement durable pour construire l'avenir. In A. Legardez et L. Simmoneaux, Développement durable et autres questions d'actualité. Questions socialement vives dans l'enseignement et la formation (pp. 33.51). Dijon: Educagri Editions.

Bader, B., Arseneau, I., Therriault, G., \& Lapointe, C. (2013). Conception des sciences d'élèves de $4{ }^{\text {ème }}$ secondaire engagés dans une démarche interdisciplinaire d'enseignement des sciences sur les changements climatiques. In Bader, Barthes, Legardez et Sauvé, Education Relative à I'Environnement: Regards-Recherches-Réflexions (Vol. 11, pp. 99-118). Montreal: Montreal. 
Bader, B., Barthes A., Legardez, A., \& Sauvé, L. (2013). Rapport aux savoirs, éducation relative à l'environnement et au développement durable. Education Relative à l'Environnement: RegardsRecherches-Réflexions, 11, 7-16.

Bader, B., \& Sauvé, L. (2011) Éducation, environnement et développement durable-Vers une écocitoyenneté critique. Québec: Les Presses de l'Université Laval-Collection L'espace public.

Barthes, A., \& Alpe, Y. (2012). Les éducations à, un changement de logique éducative, Les éducations à, quelles recherches, quels questionnements ? Les éducations à, un changement de logique éducative. Spirale, 50, 197-209.

Barthes, A., \& Alpe, Y. (2013). Le curriculum caché du développement durable. In J. M. Lange (dir.), Actes du Colloque international "Education au développement durable: appuis et obstacles à sa généralisation hors et dans l'Ecole", Rouen (26, 27 \& 28 novembre 2012, pp. 485-502). Hors-série, Penser l'éducation.

Barthes, A., \& Alpe, Y. (2016). Utiliser les représentations sociales en éducation, Collection Logiques Sociales. Paris: L'Harmattan.

Barthes, A., Alpe, Y., \& Bader, B. (2013). Questions and positions on education for sustainable development at university in France: Example of short professional cycles? Environmental Education Research, 19, 269-281.

Barthes, A., Bader, B., \& Alpe, Y. (2012). Questions and positions on education for sustainable development at university in France: Example of short professional cycles? Environmental Education Research, 19, 269-281.

Barthes, A., \& Champollion, P. (2012). Éducation au développement durable et territoires ruraux, Problématique, projet de territoire et réduction fonctionnelle de l'enseignement. Education Relative à l'Environnement, Regards-Recherches-Réflexions, 10, 36-51.

Barthes, A., \& Jeziorski, A. (2012). what kind of critical university education for sustainable development? A comparative study of European students and social representations. Journal of Social Science of Education, 11, 405-417.

Barthes, A., Zwang, A., \& Alpe, Y. (2012). Sous la bannière développement durable, quels rapports aux savoirs scientifiques? Rapport aux savoirs, éducation relative à l'environnement et au développement durable. Education Relative à l'Environnement: Regards-Recherches-Réflexions, $11,25-43$.

Bidou, J. E. (2011). Impliquer une population rurale dans la préservation de la biodiversité ? L'expérience du projet nichoirs dans la plaine en Poitou-Charentes. In Y. Alpe et Y. Girault (dir.), Actes du Colloque Education au développement durable et à la biodiversité : concepts, questions vives, outils et pratiques (pp. 179-253). Montreal: Montreal.

Bidou, J. E. (dir.) (2012). Habiter: I'ancrage territorial comme support d'éducation à l'environnement. Education relative à l'environnement: Regards-Recherches-Réflexions, 10. http://www.revue-ere. uqam.ca/

Bonneuil, C., \& Fressoz, J.-B. (2013). L'évènement anthropocène, la Terre, l'histoire et nous. Paris: Seuil, col anthropocène.

Brière, L., Sauvé, L., \& Jicking, B. (2011). Vivre ensemble sur Terre: un projet éducatif à dimension politique. Éducation Relative à l'Environnement-Regards, Recherche, Réflexions, 9, 251-263.

Chevallard, Y., \& Ladage, C. (2011). La pédagogie de l'enquête dans l'éducation au développement durable. In Y. Alpe et Y. Girault (2011), Éducation au développement durable et à la biodiversité: concepts, vives, outils et pratiques (pp. 206-229). Montreal: Refere, Uqam.

Diemer, A. (2011). Comment construire des savoirs transversaux face à l'excès d'économie ? In Y. Alpe, \& Y. Girault (dir.), Actes du Colloque Education au développement durable et à la biodiversité : concepts, questions vives, outils et pratiques (pp. 179-253). Digne: Halshs.

Diemer, A., \& Mulnet, D. (2012). Colloque international. Les représentations Nord-Sud du développement durable, Clermont-Ferrant, 8-10 décembre.

Diemer, A., \& Mulnet, D. (2013). L'éducation au développement durable. Revue francophone du développement durable, 1, 28-41. 
Dillon, J., Stevenson, RB \& Wals, A. (2016). Special section: Moving from citizen to civic science to address wicked conservation problems. Conservation Biology, 30, 450-455.

Ducamp, C. (2011). La chimie verte, approche nouvelle et responsable de la chimie. In A. Legardez et L. Simmoneaux, Développement durable et autres questions d'actualité, Questions socialement vives dans l'enseignement et la formation (pp. 145-162). Dijon: Educagri Editions.

Fahey, S. J. (2012). Curriculum change and climate change: Inside outside pressures in higher education. Journal of Curriculum Studies, 44, 703-722.

Fien, J. (1991). Ideology, political education and teacher education: Matching paradigms and models. Journal of Curriculum Studies, 23, 239-256.

Fortin-Debart, C., \& Girault, Y. (2006). État des lieux et perspectives en matière d'Éducation Relative à I'Environnement à l'échelle nationale. Rapport de recherche.

Foster, J. (2011). Sustainability and the learning virtues. Journal of Curriculum Studies, 43, 383-402. Gayford, C. (1986). Environmental education and the secondary school curriculum. Journal of Curriculum Studies, 18, 147-157.

Genevois, S., \& Leininger-Frezal, C. (2011). Les "serious games " : un outil d'éducation au développement durable? In: Y. Alpe, \& Y. Girault (dir.), Actes du Colloque Education au développement durable et à la biodiversité : concepts, questions vives, outils et pratiques (pp. 179253). Digne: Halshs.

Giral, J., \& Legardez, A. (2011). Analyser les débats sur des questions vives environnementales, quelles conditions pour une co-construction des savoirs par l'action. In A. Legardez et L. Simmoneaux (coord.), L'école à l'épreuve de l'actualité, enseigner les questions socialement vives (pp. 19-32). Paris: ESF.

Girault, Y., \& Sauvé, L. (2008). L'éducation scientifique, l'éducation à l'environnement et l'éducation au développement durable, croisements, enjeux et mouvances ". ASTER, 46, 1-21.

Girault, Y., Zwang, A., \& Jesiorski, A. (2012). Rapport aux savoirs induits dans la mise en place de différentes éducations au développement durable (EDD). Education Relative à l'Environnement : Regards-Recherches-Réflexions, 11, 61-80.

Godard, O. (2001). Le développement durable et la recherche scientifique ou la difficile conciliation des logiques de l'action et de la connaissance. In M. Jollivet (Ed.), Le développement durable, de l'utopie au concept (pp. 61-81). Paris: Elsevier SAS.

Goodson, I. (1983). Subjects for study: Aspects of a social history of curriculum. Journal of Curriculum Studies, 15, 391-408.

Gough, N. (1989). From epistemology to ecopolitics: Renewing a paradigm for curriculum. Journal of Curriculum Studies, 21, 225-241.

Greenall Gough, A. (1991). Greening the future for education: Changing curriculum content and school organization. Journal of Curriculum Studies, 23, 559-571.

Greenall Gough, A., \& Robottom, I. (1993). Towards a socially critical environmental education: Water

quality studies in a coastal school. Journal of Curriculum Studies, 25, 301-316.

Greenwood, D. A. (formerly Gruenewald). (2008). A critical pedagogy of place: From gridlock to parallax. Environmental Education Research, 14, 336-348.

Groleau, A., \& Pouliot, C. (2013). Le rapport au savoir comme outil théorique pour explorer la façon dont de futures enseignantes du primaire envisagent la physique et son enseignement. In Bader, Barthes, Legardez et Sauvé, Education Relative à l'Environnement: Regards-Recherches-Réflexions (Vol. 11, pp. 195-212). Montreal: Montreal.

Jacobs, M. (1998). "Sustainable development as a contested concept, fairness and futury". In A. Dobson (dir.), Essays on environmental sustainability and social justice (pp. 21-45). Oxford: Oxford University Press.

Jickling, B. (2009). Environmental education research: To what ends? Environmental Education Research, 15, 209-216.

Jickling, B., \& Wals, J. A. (2008). Globalization and environmental education: Looking beyond sustainable development. Curriculum Studies, 40 (1), 1-21. 
Lange, J.-M. (2008). L'éducation au développement durable au regard des spécialités enseignantes. Aster, 46, 123-154.

Lange, J.-M. (2012). Pour un curriculum de l'éducation au développement durable : entre actions de participation et démarches multiréférentielles d'investigation d'enjeux ", Rapport aux savoirs, éducation relative à l'environnement et au développement durable. Education Relative à I'Environnement: Regards-Recherches-Réflexions, 11, 23-48.

Lange, J.-M. (2013) (dir.). Actes du colloque international "Education au développement durable: appuis et obstacles à sa généralisation hors et dans l'Ecole", Rouen, 26, 27 \& 28 novembre 2012. Hors-Série, Penser l'éducation.

Lange, J.-M. (2014a). La question de la production alimentaire et le défi de la durabilité dans les rescriptions de l'enseignement général : analyse curriculaire. In J. Simonneaux, L. Simonneaux et A. Legardez (dir.), Les questions socialement vives. Revue Francophone du développement durable (Vol. 4, pp. 142-155). Clermont-Ferrand: Presse universitaire de Clermont-Ferrand.

Lange, J.-M. (2014b). Éducation au développement durable : intérêts et limites d'un usage scolaire des investigations multiréférentielles d'enjeux. In M. Fabre, $H$. Hagège et $C$. Reynaud, Les éducations à ... et le développement de la pensée critique. Education et socialisation, les cahiers du CERFEE (Vol. 36), consultable à https://edso.revues.org/872

Lange, J.-M., \& Martinand, J.-L. (2010). Education au développement durable et éducation scientifique : Repères pour un curriculum. In A. Hasni et J. Lebeaume (dir.), Enjeux contemporains de l'éducation scientifique et technique (125-154). Ottawa: Les Presses de l'Université d'Ottawa.

Lange, J.-M., \& Martinand, J. L. (2011). Curriculum de l'EDD : principes de conception et d'élaboration. In Y. Alpe et Y. Girault (dir.), Actes du Colloque Education au développement durable et à la biodiversité : Concepts, questions vives, outils et pratiques (pp. 179-253).

Lebatteux, N. (2011). La représentation sociale du développement durable d'élèves de lycée professionnel en démarche d'Agenda 21, Appuis et obstacles. In Y. Alpe et Y. Girault, Éducation au développement durable et à la biodiversité : concepts, questions vives, outils et pratiques (pp. 206229). Montréal: Refere, Uqam.

Lebeaume, J. (2012). Effervescence contemporaine des propositions d'éducations à, Regards prospectifs pour le tournant curriculaire à venir. In M. Pagoni et N. Tutiaux Guillon, Les éducations à, quelles recherches, quels questionnements? Spirale (Vol. 50, pp. 11-24). Lille: Université de Lille.

Lebeaume, J., \& Lange, J.-M. (2008). Quelle(s) didactique(s) pour une formation des enseignants "aux éducations à " ? Convoquer la complémentarité et la spécificité des didactiques ", Colloque Didactiques: Les didactiques et leurs rapports à l'enseignement et à la formation. Quel statut épistémologique de leurs modèles et de leurs résultats ? 18, 19 et 20 septembre 2008, Bordeaux.

Lee, J. C.-K. (2000). Teacher receptivity to curriculum change in the implementation stage: The case of environmental education in Hong Kong. Journal of Curriculum Studies, 32, 95-115.

Legardez, A. (2004). L'utilisation de l'analyse des représentations sociales dans une perspectivedidactique : l'exemple des questions économiques. Revue des sciences de l'éducation, 30, 647-665.

Legardez, A., \& Simonneaux, L. (2006). L'école à l'épreuve de l'actualité. Enseigner les questions socialement vives. Paris: ESF.

Legardez, A., \& Simonneaux, L. (2011). Développement durable et autres questions d'actualité. Questions socialement vives dans l'enseignement et la formation. Dijon: Educagri Editions.

Levinson, R. (2006). Towards a theoretical framework for teaching controversial socio-scientific issues. International Journal of Science Education, 28, 1201-1224.

Levinson, R. (2012). A perspective on knowing about global warming and a critical comment about schools and curriculum in relation to socio-scientific issues. Cultural Studies of Science Education, 7, 693-701.

Lucas, A. M. (1991). Environmental education. In Arieh Lewy (Ed.), The International Encyclopedia of Curriculum (pp. 770-771). Oxford: Pergamon Press. 
Martinand, J.-L. (2003). L'éducation technologique à l'école moyenne en France: problèmes de didactique curriculaire. Revue canadienne de l'enseignement des sciences, des mathématiques et des technologies, 3, 101-116.

Martinez, M.-L. (2006). Pour l'éducation à l'écocitoyenneté, à la responsabilité et à la confiance durable, observer la formation des identités singulières, sociales et professionnelles, Rapport ADEME.

Mathieu, N. (2006). La géographie rurale française face à l'utopie du développement durable : Quelles réactions, quelles perspectives ? Bulletin de l'A.G.E., 41, 39-67.

Moreau, A., Brugiere, C., \& Triquet, E. (2012). Question scientifique socialement vives et médiation participative : apport et limites d'un partenariat entre école et professionnels de l'EDD. In M. Pagoni et N. Tutiaux Guillon, Les éducations à, quelles recherches, quels questionnements ? Spirale (Vol. 50, pp. 211-223). Lille: Université de Lille.

Morin, E. (2014). Enseigner à vivre, manifeste pour changer l'éducation. Arles: Actes Sud/Play Bac. Moroye, C. (2009). Complementary curriculum: The work of ecologically minded teachers. Journal of Curriculum Studies, 41, 789-811.

Morris, M. (2002). Ecological consciousness and curriculum. Journal of Curriculum Studies, 34, 571587. Pagoni, M., \& Tutiaux-Guillon, N. (2012). Les éducations à, quelles recherches, quels questionnements? Les "éducations à". Spirale, 50, 3-10.

Reid, A. (2012). Normalising catastrophe in environmental discourse: On educational values, responses and critical imagination. Environmental Education Research, 18, 154-160.

Reid, A. (2013). Environmental education research: towards and beyond passionate, scholarly conversation. Environmental Education Research, 19, 147-153.

Reid, A. (2015). Curriculum challenges for and from environmental education, introduction of the 8th World Environmental Education Congress (Gothenburg, 29 June-2 July, 2015). Journal of Curriculum Studies, Virtual Special Issue.

Reid, A., \& Dillon, J. (2015). Major works in environmental education. London: Routledge.

Robbotom, I., \& Hart, P. (1993). Research in environmental education. Deaking: Deaking University Press.

Ross, A. (2000). Curriculum: Construction and Critique. London: Routledge Falmer.

Ross, H. (2007). Environment in the curriculum: Representation and development in the Scottish physical and social sciences. Journal of Curriculum Studies, 39, 659-677.

Sarda, A. (2011). Enseigner une question socialement vive, les intentions d'enseignants du ministère de l'agriculture. In A. Legardez et L. Simmoneaux, Développement durable et autres questions d'actualité, Questions socialement vives dans l'enseignement et la formation (pp. 293-305). Dijon: Educagri Editions.

Sauvé, L. (2006). L'organisation et la structuration du secteur de l'éducation en réponse au programme onusien du développement durable. In "Former et éduquer pour changer nos modes de vie". Liaison Energie/Francophonie, 72, 33-41.

Sauvé, L., Berryman, T., \& Brunelle, R. (2003). Environnement et développement: la culture de la filière ONU. Éducation relative à l'environnement-Regards, Recherches, Réflexions, 4, 33-55.

Sauvé, L., \& Van Steenberghe, E. (2013). Identités et engagements: Enjeux pour l'éducation relative à l'environnement. Éducation relative à l'environnement-Regards, Recherches, Réflexions, 12, 7-19. Simonneaux, J. (2011). Légitimité des savoirs et des expertises en vue d'une éducation post normale : l'exemple du développement durable (pp. 367-384). Dijon: Educagri Editions.

Simonneaux, J., \& Calmettes, B. (2013). Les sciences et les crises contemporaines. Les Dossiers des sciences de l'éducation, 29, 7-13.

Simonneaux, L., \& Simonneaux, J. (2012). Educational configurations for teaching environmental, socioscientific issues within the perspective of sustainability. Research in Science Education, 42(1), 75-94.

Simonneaux, L., Tutiaux-Guillon, N., \& Legardez, A. (2012). The epistemological and didactical challenges involved in teaching socially acute questions. Journal of social science of education, 11 . 
Smyth, J. C. (1995). Environment and education: A view of a changing scene. Environmental Education Research, 1, 3-120.

Sterling, S., \& Scott, W. (2008). Higher education and ESD in England: A critical commentary on recent initiative. Environmental Education Research, 14, 386-398.

Theys, J. (2014). Le développement durable face à sa crise : un concept menacé, inexploité ou dépassé? Développement durable et territoires [En ligne], Vol. 5, n¹ | Février 2014, mis en ligne le 04 février 2014. doi:10.4000/developpementdurable.10196 consulté le 07 juillet 2016, https:// developpementdurable.revues.org/10196

Tutiaux-Guillon, N. (2011). Le développement durable en France, suffit-il de prescrire une question vive pour qu'elle existe à l'Ecole. In A. Legardez et L. Simmoneaux, Développement durable et autres questions d'actualité. Questions socialement vives dans l'enseignement et la formation (pp. 215230). Dijon: Educagri Editions.

Urgelli, B., Simonneaux, L., \& Le Marec, J. (2011). Complexité et médiatisation d'une question socialement vive, le cas du réchauffement climatique. In Legardez et Simmoneaux, Développement durable et autres questions d'actualité, Questions socialement vives dans l'enseignement et la formation (pp. 67-88). Dijon: Educagri Editions.

Vergnolle-Mainar, C. (2011). La géographie dans l'enseignement, une discipline en dialogue. Rennes: Presses Universitaires de Rennes, collection didact géographie.

Vermersch, P. (2011). L'entretien d'explicitation, Issy-les-Moulineaux, ESF Editeur, collection Pédagogies (220 pp).

Vidal, M., \& Simonneaux, L. (2011). Jeux de rôle et simulation, sensibiliser les élèves à la gestion d'écosocio- systèmes conflictuels. In A. Legardez et L. Simmoneaux, Développement durable et autres questions d'actualité. Questions socialement vives dans l'enseignement et la formation (pp. 53-66).

Dijon: Educagri Editions.

Zaccai, E. (2011). 25 ans de développement durable, et après? [25 years of sustanable developement, en then?]. Paris: Presses Universitaires de France.

\section{Notes}

1. ANR-BLAN-08-135.

2. The SDGs show how far these concepts, once deemed radical and idealistic, are now firmly embedded in the mainstream of policymakers' agenda. This is something to celebrate. (G.H. Brundtland, 2015)

https://www.huffingtonpost.com/gro-brundtland/only-a-just-and-strong-climate-deal-canavert-

disaster_b_8655130.html

3. The bibliographies cited in these categories serve as illustrations, and in no way exclude all those that characterize these positions.

4. https://www.tropes.fr/

5. https://products.office.com/fr-fr/excel

6. We ensure here that the criterion of equality of class width is respected. The width being the difference between the highest value and the lowest value. From the global minimum ' $a$ ' of the data and the overall maximum ' $b$ ' of the data, we calculate the class boundaries 'hi' using a simple arithmetic progression whose common difference is $k=(b-a) /(n-1)$. A variant of this method consist of using ' $k$ ', value of the standard deviation of the data, as the width. If ' $n$ ' is odd, the boundaries of the median class are ' $m-k / 2, m+k / 2$ ' where ' $m$ ' is the data average. If ' $n$ ' is even, ' $m$ ' is the upper boundary of the class number ' $n / 2$ '.

\section{Notes on contributors}

Angela Barthes, PhD, Full Prof in sciences education. Angela's research interest includes knowledge transmission and education in territorial development (including education for sustainable development, heritage, citizenship, territories, etc). 
Jean-Marc Lange, PhD, Full Prof in sciences education. His research interest includes didactics (sciences) and education for sustainable development. 